\title{
UVODNIK
}

\section{REPUBLIKA SLOVENIJA - PRVIH SAMOSTOJNIH PETINDVAJSET LET V MEDNARODNEM VARNOSTNEM OKOLJU}

Leto 2016je bilo za Slovenijo pomembno zveč različnih vidikov. Miniloje petindvajset let, odkar imamo samostojno državo. Ravno toliko časa samostojno skrbimo za svojo varnost. Že leta 1990 smo se začeli pripravljati na velike spremembe. Omenim lahko plebiscit o samostojnosti ob koncu leta, ki je bil pomemben za vse preostale aktivnosti leta 1991, in zgodovinski datum 25. junij, ko sta bili sprejeti Deklaracija o neodvisnosti in Temeljna ustavna listina o samostojnosti in neodvisnosti Slovenije, ki sta bili razglašeni naslednjega dne. 27. junija se je $\mathrm{z}$ napadom Jugoslovanske ljudske armade začela slovenska osamosvojitvena vojna, ki je trajala deset dni.

Leta 1992 smo pristopili k Organizaciji za varnost in sodelovanje v Evropi (OSCE) in postali 176. članica Organizacije Združenih narodov. Demokratično izražena volja za približevanje Slovenije Natu je bila prvič jasno izražena v dopolnilih k Resoluciji o izhodiščih zasnove nacionalne varnosti leta 1994. Takrat smo pristopili k programu Partnerstva za mir, s katerim se je začela pot $\mathrm{k}$ pridruževanju tej politični in varnostni organizaciji.

Pozneje leta 2003 smo se na dveh posvetovalnih referendumih opredelili o tem, ali želimo svoji prihodnost in varnost ustvarjati s članstvom v Evropski uniji in Natu.

29. marca 2004 smo postali država članica zveze Nato, prvega maja pa je Slovenija postala še članica Evropske unije. Našteti dogodki in dejavnosti dokazujejo uspešno razvojno pot samostojne države, ki je z veliko energije in medsebojnim sodelovanjem ter z uspešno zunanjo politiko in kakovostno diplomacijo zelo veliko dosegla na svoji precej kratki razvojni poti.

Nekatere že naštete dejavnosti, ki spadajo na področji zunanje politike in diplomacije, se dotikajo tudi področij obrambe in vojske. Pri razvoju Slovenske vojske je bilo veliko pomembnih mejnikov. 
Naj ob tej priložnosti omenim 15. maj 1991, ko so na Igu pri Ljubljani in v Pekrah pri Mariboru začeli služiti vojaški rok prvi slovenski naborniki na domačih slovenskih tleh.

Konec leta 1994 je bil z dvotretjinsko večino sprejet Zakon o obrambi, ki med drugim pomeni konec Teritorialne obrambe in začetek Slovenske vojske z veliko začetnico. Maja 1995 pa je bil sprejet sklep, da se za Dan Slovenske vojske določi 15. maj.

Leta 1997 smo prvič poslali v mednarodno vojaško in humanitarno operacijo Alba pripadnike Slovenske vojske. Od takrat do konca leta 2016 je Slovenija k mednarodni varnosti veliko prispevala, saj je Slovenska vojska v tem obdobju v mednarodne operacije in na misije napotila 11.357 pripadnic in pripadnikov.

Leta 2003 je v Sloveniji zadnja generacija služila obvezni vojaški rok, saj je Slovenska vojska prešla na poklicno vojsko s pogodbeno rezervo. Leto pozneje, ko smo postali Natova članica, so v mednarodno operacijo in na misijo Isaf v Afganistan odšli prvi pripadniki Slovenske vojske.

O razvojnih obdobjih na vojaškoobrambnem področju med slovensko samostojnostjo sta že pisala Anton Grizold in Alojz Šteiner. Šteiner je razdelil razvojna obdobja Slovenske vojske na obdobje od 1991 do 1994, ki ga poimenuje obdobje Teritorialne obrambe, in obdobje od 1995 do 1999 kot obdobje reorganizacije Slovenske vojske z začetki mednarodnega vojaškega sodelovanja. Obdobje od 2000 do 2004 je poimenoval obdobje priprav na vstop v Nato in začetek profesionalizacije ter preoblikovanja Slovenske vojske, obdobje od 2005 do 2010 pa obdobje integracije v Nato in vojaške strukture Evropske unije ter nadaljevanje preoblikovanja Slovenske vojske. Opredelitve obdobij in njihovih značilnosti za čas po letu 2011 še nimamo, nedvomno pa ga je zaznamovala finančna kriza, ki je v večini držav zavezništva in držav članic Evropske unije povzročila zniževanje deleža sredstev, namenjenih za obrambo. V zavezništvu so postali pomembni pametna obramba, nišne zmogljivosti in druge aktivnosti, sprejete na vrhu Nata, ki je leta 2012 potekal v Chicagu, leta 2014 v Walesu in 2016 v Varšavi.

V Sodobnih vojaških izzivih je več avtorjev pisalo o sodobnih temah po letu 2011 in tako prispevalo $\mathrm{k}$ razvoju vojaškoobrambnih vsebin. Usmeritve se nadaljujejo tudi v tej številki.

Zunanji ameriški pogled na obrambne reforme in Slovenijo kot del mednarodnega okolja z nami deli Thomas Durell Young, ki je napisal prispevek Izziv za obrambne reforme v Srednji/Vzhodni Evropi: primer Slovenije. Smo v petindvajsetih letih razvili sodobne oborožene sile in lahko uspešno prispevamo k skupnim zmogljivostim v mednarodnem okolju ali nas čaka še veliko dela na obrambnem področju? 
Zmanjševanje virov za obrambo je povzročilo spremembe v državah članicah EU in zavezništvu. Vida Žurga v prispevku Nova sodobna grožnja nacionalni varnostiproračunska grožnja poudarja pomen samozadostnosti nacionalno-varnostnega sistema in kako je bila ta samozadostnost preizkušena na primeru migrantske krize.

Viktor Potočnik nadaljuje svojo trilogijo. Tokrat je pripravil prispevek Četrta generacija vojskovanja (2. del), Celovita prenova nacionalno-varnostnega sistema. Kot omenja, so nekateri avtorji pred kratkim predstavili nekaj predlogov in pomislekov o sedanjem sistemu nacionalne varnosti in nujnih spremembah, vendar se kaj določenega ni spremenilo. Potočnik je natančnejši in jasnejši.

O pomenu strateških komunikacij je pisalo veliko avtorjev. Kako pa je področje strateških komunikacij urejeno v Natu? Na to vprašanje odgovarja Nina Raduha v prispevku Natov koncept strateških komunikacij v Republiki Sloveniji, s poudarkom na Slovenski vojski. To ni samo stvar Slovenske vojske, temveč države kot celote in bi moralo biti pomemben del njenega strateškega komuniciranja. Pa je v resnici tako?

Igor Prelog meni, da je lahko bojno letalstvo zlasti primerno za zračno podporo protiuporniškemu delovanju zaradi mnogih prednosti, ki jih ima pred visokotehnološkim bojnim letalom z reaktivnim pogonom. O tem, kako bi lahko v protiuporniškem delovanju znotraj zavezništva pomagala tudi Slovenija, piše v prispevku Lahko bojno letalstvo v protiuporniškem delovanju in analiza uporabe Pilatusa PC-9.

Gregor Jazbec je napisal prispevek Psihologija boja: raziskava vojakovega doživljanja vojne in psihičnih posledic, ki jih povzroča bojevanje. Gre za zahtevno temo, ki predstavlja skrajne vidika bojevanja. Avtor je opravil raziskavo o doživljanju vojne in psihičnih posledicah med vojaki udeleženci različnih vojn na naših tleh in rezultate primerjal s podobnimi raziskavami v drugih državah.

Želimo vam prijetno branje in si želimo, da vas vzpodbudi tudi k pisanju. 